\title{
Carceral Citizenship as Strength: Formerly Incarcerated Activists, Civic Engagement and Criminal Justice Transformation
}

\author{
Justin M. Smith ${ }^{1} \cdot$ Aaron Kinzel $^{2}$
}

Accepted: 19 October 2020 / Published online: 23 November 2020

(c) Springer Nature B.V. 2020

\begin{abstract}
During the era of mass incarceration, a history of felony convictions and imprisonment imposes legal and extra-legal sanctions that strip individuals of rights-what Miller and Alexander (2016) call "carceral citizenship." Despite the wide-reaching structural constraints that accompany the identity of being formerly incarcerated, many individuals enact their agency with civic engagement to reshape boundaries around individual and collective identity. Building from past convict criminology research (e.g., Ross and Richards 2003), we address the gap of including formerly incarcerated people into policymaking and community organizing around penal system reform. We offer expanded conceptualization of "carceral citizenship" and provide a framework for the transformation of practices that constitute carceral systems. As Goodman and colleagues (2017) demonstrate, the reformation of penal systems is not simply a result of the mechanical swing of a pendulum. Instead, the ongoing contestation between different stakeholders shapes criminal justice. Borrowing foundational theoretical concepts from multiple critical criminology perspectives, we frame the role of "carceral citizenship" within the transformation of the penal system reform.
\end{abstract}

\section{Introduction: The Carceral State and Its Transformation}

In an extensive analysis of politics in the United States (US) and the carceral state, Gottschalk (2016: 275) argues that "major national organizations committed to social and economic justice are vexed with subtle biases that keep them from mobilizing on behalf of the most marginalized groups in the USA, including offenders and ex-offenders." Within interest group politics, generally, the lack of "affirmative advocacy" in

Justin M. Smith

smithjm@uncw.edu

Aaron Kinzel

atkinzel@umich.edu

1 Department of Sociology and Criminology, University of North Carolina, Wilmington, USA

2 Department of Criminology and Criminal Justice Studies, University of Michigan-Dearborn, Dearborn, USA 
organizational mobilization and policy decision-making often fails to centralize the needs of the most disadvantaged (Strolovitch 2008). Specific to the focus here, representation of those directly impacted remains a key missing element for a more encompassing, broader movement to resist the carceral state.

The history of art, biographical narratives, and social scientific evidence illustrate the myriad "pains of imprisonment" (Sykes 1958). The harms inflicted by prisons are numerous and we are unable to document them fully here. Nevertheless, comprehensive and clear analyses abound (e.g., Irwin 2005; Reiman and Leighton 2016; Ross 2009; Wacquant 2009). And we can note the unprecedented psychological and collective harms instituted by the carceral state over the last several decades in the US: (1) the sheer numbers and racial disproportionality that constitute mass incarceration (Alexander 2010; Garland 2001); (2) the psychological harms that result from conditions such as the absence of individual autonomy, overcrowding, solitary confinement, and threats of violence (National Research Council 2014); and (3) the post-imprisonment collateral consequences of political disenfranchisement (Manza and Uggen 2006), as well as restrictions relating to employment, health care and housing (Mauer and Chesney-Lind 2002) that accumulate to form a state of "carceral citizenship" (Miller and Alexander 2016; Miller and Stuart 2017).

Miller and Stuart (2017: 533) point out in their conceptualization of "carceral citizenship," however, that this identity allows some (perverse) benefits, including "access to goods and services reserved for formerly incarcerated people and the symbolic benefits of public regard for those who have 'made good' (see Maruna 2001)." These symbolic benefits are apparent when individuals use their first-hand experience of incarceration and apply it toward justice activism. While their analysis rightfully focuses on how "carceral citizenship" relegates individuals to an alternate legal reality, the observation that carceral expansion has produced an alternative citizenship category also suggests the potential socio-political power of some within this collectivity.

Importantly, Flores (2018) provides comprehensive evidence of this emerging phenomenon. His research shows that formerly incarcerated individuals are reshaping the meaning of carceral reform and demonstrates that elites do not have a monopoly over this reform. As Flores' unique and contoured analysis (discussed further below) illustrates, the ascendency of formerly incarcerated participants and leaders in mobilization actions is gaining recognition. Yet, a number of challenges and barriers continue. This article is an intellectual endeavor into conceptualizing and theorizing carceral system transformation and the role of "carceral citizenship" among the formerly incarcerated.

In this article, we build on the foundational work of multiple critical criminological perspectives and add further conceptualization to the concept of "carceral citizenship." For decades, convict criminology has highlighted the strengths and contributions of the formerly incarcerated in justice reform and knowledge production. Therefore, our effort to conceptualize further "carceral citizenship" relies heavily on convict criminology to illustrate the importance of formerly incarcerated voices in the transformation of the carceral system. We also rely on the framework of restorative justice to argue for the inclusion of those who have experienced (and suffered from) incarceration within collective actions and organizations working toward transformation of the carceral system. In addition, we are informed by constitutive criminology, which demonstrates that recognition of the lived experience of marginalized groups moves us toward "replacement discourses" in efforts to reconstruct discourse of "crime" and "law" (Henry and Milovanovic 1996). We use these various criminological perspectives to conceptualize how "carceral citizenship" contains advantages and not only disadvantages. 


\section{The History of Carceral Development: Whose Voices?}

Arguing for the inclusion of marginalized voices in academic and political discussion is anything but new (Alinsky 1946; Bosworth 1999; Combahee River Collective 1977). Specifically, the struggle to include formerly incarcerated people in the production of knowledge and social policy has been ongoing for several decades (Ross and Richards 2003). Yet, as we discuss below, there has been a swell of activism in recent years. Noting the desire to synthesize research on activism and civic engagement among the formerly incarcerated and to place this research within a theoretical and historical framework, we devote this part to situating the current penal reform era in context.

In their historical analysis, Campbell and Schoenfeld (2013) demonstrate how the development of the "new penal order" in the last quarter of the twentieth-century was replete with complexities, contradictions, and variations. Rather than one uniform explanation for the unprecedented national-level trend in imprisonment in the US, mounting scholarly analysis demonstrates the specific local-, state-, and national-level dynamics involved in this development. While this development includes many intricacies and contradictions and has varying labels (Alexander 2010; Garland 2001; Simon 2007; Wacquant 2009), Campbell and Schoenfeld (2013: 1379) summarize the general sentiment among leading scholars:

the new order is characterized by a set of ideas, including that the purpose of prison is incapacitation and retribution, that criminals are "other" and not worthy of redemption and that being labeled soft on crime is the ultimate political liability or conversely that tough-on-crime credentials are a political necessity. It contains a specific "penal field" where penal policies are shaped by politicians, law enforcement, and victims' organizations rather than by judges, social workers, criminologists, or community organizations...And it includes penal policies with one primary goal: to incarcerate or "supervise" masses of criminal offenders for long periods of time. As a result, the new penal order is distinguished by uniquely high and racially disproportionate incarceration rates and an expansive correctional supervision apparatus.

Political mobilization of criminal justice officials and victims' rights groups played a determining role in this new penal order. Across three distinct periods, the professionalization of criminal justice officials-from police chiefs and sheriffs to prosecutors to correctional officers - facilitated their political mobilization, particularly at local and state levels. Alongside the mobilization of criminal justice officials, victims' rights groups asserted powerful and long-standing influence on state and federal crime policy. These interest groups converged around arguments that prisons were necessary and less expensive ways to keep violent offenders off the streets and that society must stop being "soft on crime" and begin protecting the rights of victims (Campbell and Schoenfeld 2013). Politicians and interest groups, such as police associations, prosecutor associations, and prison officers' unions, "developed a formidable bloc that skillfully used the state's neopopulist political institutions to produce some of the country's harshest sentencing laws" (Goodman et al. 2017: 104: see also Page 2011). ${ }^{1}$

\footnotetext{
1 Interest group politics certainly do not constitute the entirety of reasons for the turn toward punitiveness and retribution, and the influence of interest group messaging varies across time periods and local context. Political innovations and institutional practices are set in structural economic factors and historical racial inequality that exert conditional influences on shifts in the penal order (Campbell and Schoenfeld 2013; Shah 2017).
} 
Throughout this period of carceral buildup, opposition continued-typically from subordinate actors in the legal, penal and political fields (Goodman et al. 2017). In addition, several subversive groups and actors, who had struggled persistently prior to carceral expansion, continued to do so, encountering some success when political opportunities arose. At the same time, however, political arguments across the political spectrum pressing for "law and order" and punitive policy continued and were never silent.

These recent historical analyses demonstrate how the varying voices are rarely quiet on issues of prison and punishment. Whether small-scale fights or macro-political struggles, as Bosworth (1999: 130) argues, "resistance, like power, is everywhere." ${ }^{2}$ Specifically, incarcerated and formerly incarcerated people have engaged in a long and ongoing struggle against the pains of imprisonment (Law 2009; McAnahy and Tromanhauser 1977; Thomas 1988; Thompson 2017). Even under the power structure of the prison, where freedom to decide how to live life is denied systematically and agency is constantly under attack, acts of resistance are important to uncover and recognize. In a study of women in prison, Bosworth (1999) observed they were rarely completely incapacitated. Instead, despite the overwhelming power of the institution, they discovered strategies to express creativity, religious beliefs, and sexuality. For instance, in the negotiation of power, they engaged in relatively minor acts and rebellions (e.g., verbal challenges and modes of dress). Similarly, Ross (2009) outlined resistance strategies of insubordination, litigation, "monkeywrenching," passive-aggression, and self-injury. Werth (2012) described how these types of resistance continue after prison. His study found that parolees assert their autonomy and embody their reformed subjectivity through acts of subversion (e.g., breaking curfew, socializing with prohibited others). Overall, these studies show the history of political and civic engagement among incarcerated and formerly incarcerated people. We turn now to the theoretical and policy importance of these actions.

\section{A Theoretical Cocktail: Carceral Citizenship, Convict Criminology, Constitutive Criminology, Peacemaking Criminology and Restorative Justice}

\section{Carceral Citizenship}

"Carceral citizenship" developed within the carceral age to reshape the social life of the criminalized poor (Loyd 2015; Miller and Alexander 2016; Miller and Stuart 2017). ${ }^{3}$ Though similar, "carceral citizenship" is distinct from conceptualizations of "second-class citizenship" or "custodial citizenship" (Weaver and Lerman 2010) in that it "begins at the moment of a criminal conviction and is distinguished from other forms of citizenship by the restrictions, duties and benefits uniquely accorded to carceral citizens, or to people with

\footnotetext{
${ }^{2}$ Bosworth (1999:129-130) argues against pessimistic views of resistance and states that Foucault, himself, makes clear that the "'plurality of resistances' which exist within any system of power relations are not 'only a reaction or rebound, forming with respect to the basic domination an underside that is in the end always passive, doomed to perpetual defeat' (Foucault 1980: 96). Rather, resistance, like power, is everywhere. While it is often imbricated within the power structure, it can also enable change and revolution."

3 Smiley (2014) also provides an insightful and illustrative analysis of these processes and uses the term "neo-civil death."
} 
criminal records" (Miller and Stuart 2017: 533). ${ }^{4}$ It places particular responsibilities on carceral citizens and subjects them to laws that other citizens do not face. In Miller and Stuart's (2017: 536) conceptualization, "carceral citizenship" contains three core features: (1) laws that shape engagement of formerly incarcerated people with labor and housing markets, and with social and public welfare services, as well as impact family and civic life; (2) practices of supervision, correction and care are available to carceral citizens that are otherwise unavailable to those who have not been convicted; and (3) care, management, and sanctioning of carceral citizens extends beyond the formal criminal justice system and involves third parties across the public and private sphere.

This collection of laws, entitlements and duties constitute an alternate legal reality. The three features facilitate a process of translation in which a "criminal record makes the essence of the criminalized subject legible, or readable, to others" (Miller and Stuart 2017: 537; see also Pager 2008). This translation process leads to dire vulnerability and social exclusion (Clear 2007; Western 2006). In addition, within this process of translation, different types of convictions (e.g., "sex offenses" vs. "non-violent offenses") bring about different consequences and one's criminal record results in different outcomes across each stage of the criminal justice process.

Without neglecting or belittling these countless examples of exclusion and burden, there is room to develop the features of "carceral citizenship" by noting the authenticity it carries within civic engagement around criminal law and justice (Maruna and LeBel 2009). As Miller and Stuart (2017) state, carceral citizens have agency and there is still much that is not known about the relationship between "carceral citizenship" and democracy. To be sure, the collective experience of "carceral citizenship" is not monolithic. Indeed, the original statements by Miller and colleagues focus on classed and racial elements- "that carceral expansion has in part produced a new form of citizenship for the Black and Brown poor" (Miller and Alexander 2016: 294) —not simply living with a felony record (Miller and Alexander 2016; Miller and Stuart 2017). Any conceptualization of "carceral citizenship" must account for intersecting identities, differing histories of convictions, and the varying stigmatization they carry (Williams 2019). Smiley (2019) draws out, for example, how optimistic aspirations of participating in movement-building among a group of formerly incarcerated Black men was met with fear of re-arrest, especially for those still on parole. Given these complexities, a mix of critical criminological approaches (including many not highlighted here) can help us understand "carceral citizenship," its role in civic engagement, and work toward its deconstruction.

\section{Convict Criminology}

In the early 1990s, convict criminology—influenced by the work of John Irwin (1970, 1980)_emerged to address the inadequate representation of voices of people with felony convictions in criminology, as well as in broader policy reform debates (Ross and Richards 2003). Highlighting the strengths that formerly incarcerated perspectives contribute to the fields of criminology and criminal justice is a foundational element of convict criminology. Criminology, as an academic field, has ignored and excluded the perspective of people with experience of being caught in the criminal justice machine (beyond using them as subjects

\footnotetext{
4 Although "carceral citizenship" includes the effects on those with criminal records and not only those who have been incarcerated, we focus on the formerly incarcerated due to their particular experiences.
} 
in data collection). As Mobley (2003) delineates, academia encourages detachment from the personal and engages in dehumanizing research methods and language that reproduce a non-reflexive construction of knowledge which, in turn, perpetuates systemic harms. This research tends "to gloss over the horrors of prison, inventing a sanitized presentation, without the smell of fear and noise of desperation known so well by the men and women that live in cages" (Richards 2013: 377). Convict criminologists have produced numerous, wide-ranging publications that challenge status quo criminological theory, epistemology and evidence, especially those related to prisons (Jones et al. 2009; Richards 2013; Ross and Richards 2003; Ross et al. 2014; Tietjen 2019).

Indeed, convict criminologists have laid the groundwork for problematizing criminal justice knowledge production. Lenza (2011: 162) places the construction of criminal identities by institutions of state power and its relationship to social science within the long history of colonialism, and he calls upon critical criminology to "develop a new synthesis of critical theory with postmodern theories and methods to restore a measure of balance and social justice within the study of criminal justice and criminology." To this end, convict criminology's theoretical perspectives emphasize the importance of reflexivity (Bourdieu 1999) and share the methodological values of "criminological verstehen" (Ferrell 1997). In turn, ethnographic and autoethnographic approaches draw upon the unique and situated first-hand experience of incarceration. Much scholarship from convict criminology takes advantage of the insider perspective to dismantle the false dualities of "victim" and "offender." Drawing from victimology's insistence that criminology largely ignores and marginalizes victims' voices, this perspective strives to uncover the totality of the carceral experience (Leyva and Bickel 2010). ${ }^{5}$

Sharing the desire for quality research through fair and impartial methods with social science, generally, convict criminologists have recognized the potential contamination that the insider perspective and emotionalism can bring to research around prisons and state surveillance. Yet, emotions do not necessarily invalidate this knowledge and can actually contribute nuanced contextualization (Jewkes 2012). As Newbold and colleagues (2014: 441) argue, "[p]rovided it does not unrealistically skew the researcher's perception or analysis, insider input may therefore be regarded as an essential thread in the tapestry of criminological inquiry."

Over the last two decades, while some scholars in the "very fluid and dynamic network" of convict criminology have concentrated on scholarly research, others have embraced their role in activism and policy reform (Ross et al. 2016). Among these varied and numerous efforts, convict criminologists have engaged in policy activism, such as working to change sentencing laws and guiding community reentry policy (Ross et al. 2016). Others, like Richards and Jones (1997) and Newbold (1998), have been contracted by government offices to publish criminal justice research reports. These works of public convict criminology are not only studies on the formerly incarcerated, but by them.

In response to the lack of humanity in utilitarian criminological policy and research, the emotional proximity of formerly incarcerated researchers, advocates, and activists to the experience of incarceration can be used as a resource in cultivating knowledge on prisons (Jewkes 2012). Furthermore, the experiences of formerly incarcerated individuals are more likely to engender compassion and concern by the general public than lifeless data sets. Based on these foundational struggles for recognition and cultivating civic engagement

\footnotetext{
5 Aural criminology, narrative criminology, and photovoice projects are examples of how others are now using interdisciplinary methods to focus on these voices.
} 
(Grigsby 2012) within and beyond academia, we combine related theoretical frameworks to understand the importance of formerly incarcerated voices as an element of "carceral citizenship."

\section{Constitutive Criminology}

Henry and Milovanovic (1994: 110) provide many theoretical insights related to "carceral citizenship" within their constitutive criminology perspective, which is oriented toward understanding how crime, victims, and social control are constituted as realities, how to deconstruct these realities, and how we may reconstruct less harmful alternatives. Importantly, the constitutive approach outlines policy alternatives that deconstruct either/or dichotomies between punishment and treatment and offers a framework toward reconstruction.

Their conceptualization of "replacement discourse" is particularly relevant to the discussion of "centering the margins" in criminological knowledge production and the process of translation in "carceral citizenship." As Henry and Milovanovic (1996:204) observed, "[r]eplacement discourse is directed toward the dual process of deconstructing prevailing structures of meaning and displacing them with new conceptions, distinctions, words, and phrases, which convey alternative meanings." Where the dominant legal discourse silences their voice and experience, the participation of the marginalized is elemental - both in the reconstruction of structures of meaning and in their own process of becoming. A foundation for the creation of replacement discourse lies in the work of Freire (1985: 92), whose notion of conscientization envisions a process where the disenfranchised "exercise the right to participate consciously in the socio-historical transformation of their society." Along with other activists-perhaps those with positionality that heightens social recognition in dominant structures (the "cultural revolutionary")—-marginalized individuals participate in a dialogical pedagogical and political practice (Henry and Milovanovic 1996).

While the inclusion of marginalized voices is important, they are not automatically replacement discourses. Narratives from oppositional groups "are often replete with the very core imageries, metaphors and signifiers that are the supports of a hierarchical and dominating apparatus" (Henry and Milovanovic 1994: 128). ${ }^{6}$ For example, formerly and currently incarcerated activists may advocate the use of punishment for those who "truly deserve it." Indeed, Maruna (2001) shows how men who seek redemption from past transgressions often align with traditional values and distance themselves from "real criminals." In an analysis of autobiographies of incarcerated and formerly incarcerated people, part of Lynn's (2019) conclusion states that "challenging mass incarceration and racism via prison narratives in public today becomes a tool of legitimizing neoliberal visions of future social change." Milovanovic (1997) speaks of this in terms of the dialectic of control, or the two sides of transpraxis, where negation and affirmation of the structure of control can coexist. Thus, these efforts must be concerned with how individuals are constituted by multiple sites of interlocking struggle. To put it a little more simply, some formerly incarcerated

\footnotetext{
${ }^{6}$ In addition, we are not arguing here that positions from formerly incarcerated activists that rely on the master discourse of our carceral system are entirely ineffective. Recent sentencing and parole reforms have not been based on any complete "replacement discourse" - yet, they have achieved significant life-altering outcomes for thousands of people. Though strict prison abolitionist arguments may label these measures as "reformist reform," increasing parole approval rates and shortening lengths of sentences through legislation have clear and meaningful consequences for the individuals serving time in prison and their loved ones.
} 
people face more stigma and resistance than others based on their overlapping identities; actions to change the system must be concerned with how they may liberate some but also maintain the repression of others.

Replacement discourse then must be a language of "transpraxis"- a notion that "assumes that critical opposition must be aware of the reconstitutive effects- the reproductions of exploitative relations of power-in both supportive and oppositional activity" (Henry and Milovanovic 1994: 129-130). The demanding approach of transpraxis requires the "diverse discursive subject-positions" of the policed and incarcerated in policy and intellectual discussion to construct alternative narratives of justice. Replacement discourse addresses some of the critiques by De Haan (1990: 159), whose "politics of redress" argues for "practical discourse," where repressed and marginalized discursive practices are genuinely considered in the reality-making process.

Evidence from Flores (2018) demonstrates that formerly incarcerated activists are carrying out discursive practices that, in the words of Milovanovic (1997: 82), "transform events that they see or experience as micro-events into summary representations, or mind patterns, by relying on routine practices through which they convince themselves of having achieved the appropriate representation of these events; these are then objectified in coherent narrative constructions." Organizations with formerly incarcerated members facilitate their use of "therapeutic discourse" and "redemption scripts" to reshape state-citizen relationships and assert themselves as the "experts" (Flores 2018), not only shaping policy but also how their identity is translated. By making themselves appear "redeemed," their criminal record paradoxically is a mark of authenticity.

\section{Restorative Justice and Peacemaking Criminology}

Milovanovic and Henry's concept of "transpraxis" converges with insights from restorative justice and peacemaking criminology that "call[] upon us to refuse to invest in a social ethic that separates us from one another and instead to visualize all people-including those responsible for serious harms-as being connected" (Wozniak et al. 2008: 156). Restorative justice is founded on three pillars: harms and needs, obligations, and engagement (Zehr 2015). The necessity of engagement, most relevant to concerns here, "implies involvement of an enlarged circle of parties as compared to the traditional justice processes" (Zehr 2015: 24). While restorative justice usually occurs after individual-level interpersonal conflict and harm, its application to systemic institutional processes is not without precedent or relevance. Including the collective memory of groups who have faced injustice - in this case, mass incarceration and the War on Drugs-can serve as an innovative practice toward "restorative reentry" and "historical justice" (Lynn 2018). In order to transform through a restorative framework, the process of defining policy and practice around justice must then engage with those who have been impacted most directly by the harms of imprisonment.

As others have done, we borrow from the South African Truth and Reconciliation Commission to outline key concepts in the process of repairing systemic and historical harms. The seminal foundation of the Truth and Reconciliation Commission (TRC) included its requirement to help restore the human and civil dignity of victims "by granting them an opportunity to relate their own accounts of the violations of which they are the victim" (Truth and Reconciliation Commission 1998: 55). Many of these insights are transferable to discourse on the US carceral system and its harms. 
The TRC began by highlighting that the very definition of "reconciliation" was contested. Essential elements nonetheless did emerge from debates within and outside the commission. First, reconciliation was seen as a goal and a process. Second, reconciliation was understood to occur on multiple levels: between individual victims and perpetrators, at the community level, and at the national level.

Bringing together voices of the many stakeholders of harm and conflict also raises the problem of defining "truth." As the Final Report of the TRC asked, "what about truth—and whose truth?" In the final summary, four notions of truth were noted: "factual or forensic truth; personal or narrative truth; social or 'dialogue' truth and healing and restorative truth" (Truth and Reconciliation Commission 1998: 110). Regarding personal or narrative truth, the Truth and Reconciliation Commission (1998: 112) explained that "by telling their stories, both victims and perpetrators gave meaning to the multi-layered experiences of the South African story." Dialogue between those harmed by and those who have contributed to harm creates the possibility of moving in the direction of social and restorative justice.

Perhaps most notably, the TRC showed us that any attempt at restoration and reconciliation occurs within a context of historical and structural inequalities. Because any attempt at transformation of the carceral system through formal policy and cultural change takes place within the structure of economic and racial inequalities where it has developed, the inclusion of formerly incarcerated voices should be viewed as a contribution to a much longer-term strategic undertaking.

\section{Incarcerated Voices in Prison Reform: Research and Recent Developments in a New Era}

\section{The Development of a New Era in Penal Development}

The emergence of mass incarceration and the carceral state entails a variety of social forces and distinguishable historical periods (Campbell 2018). Specifically, Campbell and Schoenfeld (2013) demarcate three periods that led to the size of prison populations at the beginning of the twenty-first century. Recent developments suggest we have entered a new era where modest changes are drawing away from the dramatic growth of the carceral state (e.g., declining prison populations, expanding expungement of criminal records).

Along with the measured recognition of the problems of mass incarceration among some policy makers, professional organizations of formerly incarcerated activists and advocates have emerged. The Obama Administration, for instance, incorporated voices of formerly incarcerated criminal justice reformers into its policy discussions. Organizations, such as JustLeadershipUSA and All of Us or None, are led by formerly incarcerated activists. Over the last several years, these organizations have not only struggled for local, state, and federal policy reform but have also formalized training and recruitment strategies for formerly incarcerated individuals. JustLeadershipUSA, for example, trains formerly incarcerated leaders in four core areas: advocacy and policy, communication, community building, and leadership and organizational management. As a result, members have had a "seat at the table" in official task forces and legislative hearings.

While modest acknowledgment of those impacted directly has grown, elite civic organizations continue to shape public discourse and inclusion of policy proposals around prisons. As Goodman and colleagues (2017: 128) state, though the 2010 s seem to have brought a level of liberalizing punishment and declining carceral state, powerful voices continue to 
"back the status quo, arguing that expansive and intensive policing, prosecution, and sentencing practices drove the US' crime drop and now protect the country from plummeting into violent chaos." Indeed, such claims have continued into the 2020s. Contestation over punishment is constant.

\section{Research on Formerly Incarcerated Activists and Engaging Carceral Citizenship}

Imprisonment and legal barriers post-release have prohibited civic engagement and community organizing among the formerly incarcerated, yet many have struggled consistently against these constraints. In their groundbreaking analysis of felon disenfranchisement and civic engagement, Manza and Uggen (2006) offer evidence of activism among the formerly incarcerated. Many of their interviewees describe desires to give back to their community through civic engagement, such as educating youth and public speaking. Like any collective, the formerly incarcerated exhibit a range of political orientations and motivations for civic engagement. Overall, Manza and Uggen (2006: 151) argue, "[f]ar from being the politically deviant or incompetent citizens imagined by those who would protect the 'purity' of the ballot box, they expressed the same types of political hopes and fears, and policy preferences, as other enfranchised groups." Yet, through formal and informal stigmatization, numerous barriers obstruct their important contribution to the democratic process. Though the experience of carceral citizenship is overwhelmingly grim, it also entails contradictory instances of utilizing this identity as a strength in socio-political activism.

Flores (2018) demonstrates how involvement in social actions exert powerful effects on policy discourse as well as on returning citizens' reintegration process. His work critiques and expands upon past anthropological, criminological, and sociological research around criminal behavior, rehabilitation, and civic engagement. Specifically, building off the work of Slessarev-Jamir (2011), Flores (2018: 4) draws from sociological studies of religion to conceptualize "faith-based community organizing for the formerly incarcerated as a form of prophetic redemption expanding the boundaries of democratic inclusion to facilitate the social integration of those furthest from the margins" (emphasis in original). Distinct forms of pastoral prophetic redemption and insurgent prophetic redemption emerge through his (Flores') participant observation of social activist and advocacy groups in Chicago and Los Angeles. Through pastoral prophetic redemption, "activists attempt to foster rehabilitation together with facilitating social integration and reducing crime," whereas in insurgent prophetic redemption, "activists attempt to explain the rights of the formerly incarcerated, but with a less explicit emphasis on personal change... [and] takes aim at the state and powerful actors, demanding the expansion of citizenship rights" (Flores 2018: 6-7).

Flores traces the history of prophetic redemption to the innovative scholar-activism of Du Bois (1899), which continues to offer insights into the social and structural causes of crime. Flores outlines how the "social ecology" scholars of the Chicago School, who, in turn, paved the way for top-down Age of Roosevelt crime control policies (roughly 1993-1973) (Hagan 2012), appropriated Du Bois' groundbreaking findings on the connections between social disorder, racial segregation, and crime. Subsequently, the mainstream American sociology of the Chicago School faced resistance from the work of Saul Alinsky (a former Chicago School student), who emphasized the importance of grassroots political mobilization and "native leadership." 
The importance of native leadership (Alinsky 1946) is echoed by the Lifers Public Safety Steering Committee of the Correctional Institution at Graterford, Pennsylvania (2004), who argue that former perpetrators who have worked to a certain point of transformation should be placed in positions where they can interact with others seeking to change their own behavior patterns. The unique forms of language, mannerisms and norms that they hold are valuable assets that others cannot replicate. Formerly incarcerated individuals discuss both their own history of wrongdoing and harm done to them. The false duality of "victim-offender," a fundamental criticism from restorative justice, applies in this context. Many formerly incarcerated individuals discuss their drive to play a role in reform actions or helping others as a way to make up for time and opportunities that they missed rather than succumbing to the exclusionary barriers they face.

Similarly, Polletta's (2006) analysis describes nuanced forms of storytelling, where the tellers assert their victimization without becoming only (or nothing more than) a victim. The power and elegance of storytelling is seen across many social movements. Polletta (2006: 116) makes clear that:

In movements against child sexual abuse and domestic battering, the notion of the 'survivor' put the emphasis on the person's agency. She or he was not merely the object of abuse but had survived it. Where the term victim also suggested an immutability (one was and would always be a victim), the term survivor pointed to the possibility of change. The message was that survivors had been grievously hurt and traumatized in lasting ways but that they had not been destroyed.

Storytellers employ the term "survivor" to signal personal agency and the possibility of change, rather than the totalizing identity of "victim." This narrative arc moves from a sense of "powerlessness and passivity to insight, enlightenment, and self-liberation" (Polletta 2006: 116). Movement storytellers claim the role of expert in democratic deliberation. From this view, having gone through victimization-such as child abuse and human rights violations-individuals embrace the role of "experts," whose knowledge can complement the insights of "credentialed leaders" (e.g., scientific or legal expertise). As Polletta (2006:86) continues,

In a deliberative setting, storytelling is equalizing, since everyone has his or her own story. Encouraging disadvantaged groups to tell their own stories can counter the silencing that comes with privileging abstract, rational discourse. More than that, personal storytelling can gain an empathetic hearing for experiences and values that are different from those of the majority.

Epstein's (1996) research on activism around AIDS illustrates how sufferers became the experts and demanded presence on federal drug research review panels. Their storytelling became a form of authoritative knowledge.

Flores (2018: 107) engages this perspective on storytelling and explains that activists "drew from redemption scripts as they resisted their exclusion, took the places of experts in legislative reform, and expanded the rights of the formerly incarcerated." These stories can become legitimized via social action groups, who provide "acceptable repertoires to share stories, such as the Christian act of bearing witness, as well as platforms necessary to enable collective and political action" (Flores 2018: 107). For Flores (2018), personal narratives can become public testimonies and can lead to subsequent collective and political action. 
This initial sociological examination of formerly incarcerated activists provides a springboard for further examination of the theoretical and practical relevance of "carceral citizenship." Next, we incorporate examples of theoretical concepts relevant to "carceral citizenship" within a brief narrative case analysis by the second author. As described in past studies: (1) mass incarceration developed a particularly salient form of "carceral citizenship" where thousands experienced collateral consequences of conviction and imprisonment; (2) a distinguishable era of resistance to mass incarceration developed over the 2010s; and (3) formerly incarcerated activists have played a formative role in this resistance by struggling to have their storytelling recognized as assets and legitimate knowledge. These developments are exemplified in the case below.

\section{The Case of Michigan Organizing and Criminal Expungement Laws: An Insider Account}

From my view, ${ }^{7}$ while formerly incarcerated people have been building small social movements for generations, they really started mobilizing in large numbers after two powerful media releases: (1) the book, The new Jim Crow: Mass incarceration in the age of colorblindness (Alexander 2010); and (2) the documentary film, The House I Live In (2013). In Michigan, there are currently dozens of formerly incarcerated leaders who work collaboratively with various local and national criminal justice reform organizations. In this sense, our common identity as formerly incarcerated individuals cultivates a collectivity. We meet frequently with criminal justice system stakeholders, such as the Michigan Legislature, elected judges and prosecutors, and Michigan Department of Corrections, as well as local and state law enforcement agencies. Furthermore, several formerly incarcerated activists in Michigan worked to ensure the voting rights of people detained pre-trial in local jails were protected during the November 2020 election. These leaders often meet in small or large groups to discuss policy reform initiatives regarding the criminal justice system. We also have small group chats via cell phone or social media to help us organize in our communities. For instance, individual formerly incarcerated leaders from particular cities or counties organize directly with our local community networks. And during the quarantine due to COVID-19 in the summer and fall of 2020, several webinars were formed to organize and raise public awareness around justice reform. In general, we target areas that have large populations of people who have been impacted directly by the justice system (e.g., Detroit, Flint, Grand Rapids), as well as regions of power and influence to support our causes (e.g., Ann Arbor, Lansing, Traverse City). I have had the opportunity to collaborate beyond Michigan to work on national issues, such as removing barriers to qualify for and receive Federal Pell Grants to increase post-secondary education while in prison. Working across state lines has been an excellent way to share best practices of organizing and policy reform with other formerly incarcerated leaders across the country.

Recently, formerly incarcerated individuals have worked to expand the list of crimes that can be expunged from one's record. Numerous organizations that either serve or are led by formerly incarcerated individuals gathered together in early 2019 to discuss building a movement to change public policy surrounding current criminal expungement statutes. In response to this organizing, the Michigan House of Representatives initiated and passed

7 This part describes participant-observation research completed by the second author. 
a package of bills in 2019, commonly referred to as "Clean Slate." Three lead organizations-Safe \& Just Michigan, JustLeadership USA, and the Detroit Justice Center-worked together to create community listening sessions to build a movement of support. I was and continue to be intimately involved in these organizing actions throughout the state and at the capitol (in Lansing). I participated in several of these community listening sessions and facilitated one in Lansing organized by another small non-profit organization, Citizens for Prison Reform. In October 2020, Governor Gretchen Whitmer (D) signed House Bills 4980-4985 and 5120, which are intended to make it easier for people who have committed certain felonies and misdemeanors to have their record expunged.

These meetings were set up as public education events to discuss various aspects of the collateral consequences of criminal conviction. While acknowledging the diverse experiences of formerly incarcerated people, we told our stories to serve as first-hand knowledge of the numerous post-conviction barriers we share. Many community members were not aware that formerly incarcerated individuals faced such a set of complex barriers due to their felony records. We discussed how these barriers enhance criminogenic factors and increase the likelihood of recidivism. Many community members, particularly middleaged people and senior citizens, asked questions about how they could help support these efforts. We responded by providing them with information on how to contact their Michigan State Representative or Senator, and we encouraged them to write emails, call, and attend "legislative coffee hours" in their community, as well as come directly to the capitol to voice their opinions. We distributed fact sheets to use as talking points for community members as well. Our original benchmark of success for "clean slate" legislation was to create an automatic expungement of criminal histories after ten years following release. Many backdoor conversations with government officials gave us the impression that there would be two specific waivers to the automatic ten-year expungement due to public safety and constituency perspective. These waivers would preclude those with a criminal sexual conduct (CSC) or murder conviction from having their record removed. While other formerly incarcerated leaders and I understood, and perhaps agreed with, the CSC exclusion, we did not agree with the murder conviction. ${ }^{8}$ In fact, in my experience, people with serious and violent convictions (such as murder), who have spent substantial time in prison, often have the best attitudes and very low rates of recidivism.

In the fall of 2019, I attended the Michigan House Judiciary Committee hearing where many individuals and organizations came to support this package of bills. While many others and I submitted a formal request to testify at the public hearing, many of us were unable to speak due to time constraints and the sheer volume of requests for testimony. The room was filled with no available seating by $8 \mathrm{am}$ in the morning. Over a dozen formerly incarcerated individuals either submitted letters of support or attempted to speak at the hearing. First-hand testimonies were combined with research of criminal records by Professor Sonja B. Starr of the University of Michigan Law School. Many individuals advocated in support of the package of bills on expungement but expressed concern about their limited scope and called on legislators to do more to help justice-impacted populations.

Written letters of support for the Michigan Clean Slate initiative illustrate the types of testimonials that formerly incarcerated activists utilize. Flores (2018) argues that these individual stories serve as collective testimonials, as they represent common prison and postprison experiences. Monica Jahner, a member of JustLeadership USA and a representative

\footnotetext{
${ }^{8}$ These examples illustrate how groups of individuals are distinguished for different treatments in policy discussions - a phenomenon described by Seeds (2017).
} 
to the Michigan Joint Task Force on Jail and Pretrial Incarceration, wrote in her letter of support to the Representative Graham Filler (R), Chair of the House Judiciary Committee:

I also thank you for making room for those most directly impacted by the issue to have a voice. For so long, we have not. For so long, we have suffered invisibly to make ends meet and provide for our loved ones long after our sentence technically ended. I am here to tell you today, it never ends. We are punished by a thousand cuts each time we are denied a job, or a place to live, for a crime that was committed sometimes decades ago. Our loved ones are punished. Our communities are punished as a result of lost wages, lost housing, lost family.

Another formerly incarcerated community member wrote:

But I will always have to stand in the shadows because of my past without any feeling that I have paid my debt to society. I was convicted of multiple non-assaultive convictions (five) during one criminal investigation that I served my time for. My felony convictions continue to deny me many basic rights of citizenship and continue to do so for decades, there is no means of remediation and no way for me to join the community in which I live wholeheartedly without expungement.

\section{And a third stated:}

I own a home. Yet, I cannot rent an apartment. I have two drug felonies, but it is a single count of armed robbery that I have on my record from 2004 that has caused the top four rental companies here to tell me that I can never rent from them....Regardless of my excellent credit score, I cannot be on a lease. Despite being cleared by the Department of Corrections to reenter prisons to provide therapy, my record permanently bars me from accessing most housing...I make the argument that permanently barring people from fully engaging in the economy unnecessarily disenfranchise thousands who could otherwise more effectively move beyond their stigmatizing record. If we truly believe in redemption, we must reflect this in our legislation.

These are just a few examples, but the statements reflect how formerly incarcerated leaders have developed a culture of carceral reform in which they empower each other and work together to decarcerate the state of Michigan and beyond. These collective efforts toward "border crossings" (Giroux 1992), where formerly incarcerated leaders are engaged in public storytelling events transgress traditional boundaries of knowledge (e.g., testimonials from corrections administrators, research sponsored by state department of corrections). ${ }^{9}$ In my experience as a formerly incarcerated individual, scholars have failed to understand the complexities of prisonization, collateral consequences of conviction and imprisonment, and the collectivity formed by individuals who have shared backgrounds within the carceral state. From these experiences, formerly incarcerated individuals can teach the public, and each other, how to build powerful movements and inform social policy.

\footnotetext{
9 The complexities of these narratives, particularly their focus on individual responsibility, as well as achievement, consumption, and social resiliency, are also sites of potential analysis. Lynn (2019) argues that this “discourse of 'responsibilization' is consistent with the cultural trope of individual responsibility and the 'responsibilization strategy' in the age of neoliberalism (Garland 2001)."
} 


\section{Conclusion}

In the conclusion of her comprehensive book on prisons and US politics, Gottschalk outlines "what doesn't work" to transform the carceral state. Among the many challenges, Gottschalk (2016: 261) argues that:

A penal reform agenda delineated primarily by evidence-based research about 'what works' will inevitably yield an agenda that is highly constrained and politically vulnerable...The fixation on emphasizing technocratic, expert-driven solutions to the problem of the carceral state denies the fundamental role that politics, emotion, and culture play in meting out punishment and in defining good and bad penal policy.

While empirical "evidence-based" policy remains a dominant movement inside criminology, its clear limitations are exposed by the complexities of public discourse around justice. First, it is most often removed from the humanity and emotion involved in the lived experience of social harm and social control. Second, its purported claims of neutrality typically leaves it muted in moral contestations over justice.

In the ongoing era where the "punishment imperative" (Clear and Frost 2015) persists but is met with emerging resistance strategies, "carceral citizenship" is a nuanced phenomenon. While it overwhelmingly changes social life for the racialized and criminalized poor, for a select number of people with experiences of incarceration, their socio-political voice is credentialed. Through this credentialed voice, formerly incarcerated storytelling holds the capacity to transform discourse-not only illuminating visceral experiences, but also fundamental moral problems.

While numerous sophisticated and tireless empirical studies demonstrate the vastness of mass incarceration and its inequalities, moral arguments mark its profound violations of human and constitutional rights (Loury 2008). In his outlining of the emptiness of liberal neutrality in political debates about justice in the US, Sandel (2009: 251) illustrates how "[t]he attempt to detach arguments about justice and rights from arguments about the good life is mistaken for two reasons: First, it is not always possible to decide questions of justice and rights without resolving substantive moral questions; and second, even where it's possible, it may not be desirable."

Over the last several decades in the US, discourse over morality or virtue in the field of justice has been monopolized by conservative and retributive arguments (Clear and Frost 2015; Sandel 2009). Pro-punishment arguments continue to appeal to emotion through horrifying stories. Other perspectives can wage resistance within these public debates which cannot be overcome by morally neutral arguments and dehumanized evidence. As Professor John Laub, a former president of the American Society of Criminology explains, "[p]rofessional criminologists should also accept the reality that "most policy issues are moral questions that cannot be answered by theory or for that matter by research... Moreover the idea that scholarly knowledge and this knowledge alone should determine policy outcomes is naïve" (2004: 18).

Rather than simply falling into endless and undiscriminating relativism, first-hand accounts and moral arguments enable more in-depth analysis (De Haan 1990). Stories of formerly incarcerated activists paint a more elaborate picture of these complex contours of justice. 


\section{References}

Alexander, M. (2010). The new Jim Crow: Mass incarceration in the age of colorblindness. New York: The New Press.

Alinsky, S. (1946). Reveille for radicals. Chicago, IL: The University of Chicago Press.

Bosworth, M. (1999). Engendering resistance: Agency and power in women's prisons. New York: Routledge.

Bourdieu, P. (1999). The weight of the world - social suffering in contemporary society. Cambridge, UK: Polity.

Brown, M. (2009). The culture of punishment: Prison, society, and spectacle. New York: NYU Press.

Campbell, M. C. (2018). Varieties of mass incarceration: what we learn from state histories. Annual Review of Criminology, 1, 219-234.

Campbell, M. C., \& Schoenfeld, H. (2013). The transformation of America's penal order: A historicized political sociology of punishment. American Journal of Sociology, 118(5), 1375-1423.

Clear, T. R. (2007). Imprisoning communities: How mass incarceration makes disadvantaged neighborhoods worse. New York: Oxford University Press.

Clear, T. R., \& Frost, N. A. (2015). The punishment imperative: The rise and failure of mass incarceration in America. New York: NYU Press.

Combahee River Collective. (1977). A black feminist statement. In B. Guy-Sheftall (Ed.), Words of fire: An anthology of African-American feminist thought (pp. 232-240). New York: The New Press.

De Haan, W. (1990). The politics of redress: Crime, punishment and penal abolition. London: Unwin Hyman.

DuBois, W. E. B. (1899). The Philadelphia negro: A social study. New York: Schocken.

Epstein, S. (1996). Impure science: AIDS, activism, and the politics of knowledge. Berkeley, CA: University of California Press.

Ferrell, J. (1997). Criminological verstehen: Inside the immediacy of crime. Justice Quarterly, 14(1), 3-23.

Flores, E. O. (2018). Jesus saved an ex-con: Political activism and redemption after incarceration. New York: NYU Press.

Foucault, M. (1980). Power/knowledge: Selected interviews and other writings, 1972-1977. New York: Pantheon books.

Foucault, M. (1990). The history of sexuality: Volume 1: An introduction. (R. Hurley, Trans.). New York: Vintage.

Freire, P. (1985). The politics of education: Culture, power and liberation. Westoport, CT: Bergin \& Garvey.

Garland, D. (2001). The culture of control: Crime and social order in contemporary society. Chicago, IL: The University of Chicago Press.

Giroux, H. (1992). Border crossings: Cultural workers and the politics of education. New York: Routledge.

Goodman, P., Page, J., \& Phelps, M. (2017). Breaking the pendulum: The long struggle over criminal justice. New York: Oxford University Press.

Gottschalk, M. (2016). Caught: The prison state and the lockdown of American politics. Princeton, NJ: Princeton University Press.

Grigsby, R. (2012). Convict criminology and social justice advocacy: Toward radical change. Journal of Prisoners on Prisons, 21(1), 81-88.

Hagan, J. (2012). Who are the criminals? The politics of crime policy from the age of Roosevelt to the age of Reagan. Princeton, NJ: Princeton University Press.

Henry, S., \& Milovanovic, D. (1994). The constitution of constitutive criminology: A postmodern approach to criminological theory. In D. Nelken (Ed.), The futures of criminology (pp. 110-133). London: Sage.

Henry, S., \& Milovanovic, D. (1996). Constitutive criminology. Thousand Oaks, CA: Sage.

Irwin, J. (1970). The felon. Englewoods Cliffs, NJ: Prentice Hall.

Irwin, J. (1980). Prisons in turmoil. Boston, MA: Little Brown.

Irwin, J. (2005). The warehouse prison: Disposal of the new dangerous class. Los Angeles, CA: Oxford University Press.

Jewkes, Y. (2012). Autoethnography and emotion as intellectual resources: Doing prison research differently. Qualitative Inquiry, 18(1), 63-75.

Jones, R. S., Ross, J. I., Richards, S. C., \& Murphy, D. S. (2009). The first dime: A decade of convict criminology. The Prison Journal, 89(2), 151-171.

Laub, J. H. (2004). The life course of criminology in the United States: The American Society of Criminology 2003 presidential address. Criminology, 42(1), 1-26.

Law, V. (2009). Resistance behind bars: The struggles of incarcerated women. Oakland, CA: PM Press. 
Lenza, M. (2011). The importance of postmodern autoethnography and ethnography in criminal justice research and policy development. In I. O. Ekunwe \& R. Jones (Eds.), Global Perspectives on Reentry (pp. 146-172). Tampere, FI: Tampere University Press.

Leyva, M., \& Bickel, C. (2010). From corrections to college: The value of a convict's voice. Western Criminology Review, 11(1), 50-60.

LIFERS Public Safety Steering Committee. (2004). Ending the culture of street crime. The Prison Journal, 84(4), 48S-68S.

Loury, G. C. (2008). Race, incarceration, and American values. Cambridge, MA: The MIT Press.

Loyd, J. M. (2015). Carceral citizenship in an age of global apartheid. Occassian, 8, 1-15.

Lynn, V. (2018). Dialogues of the War on Drugs: Towards restorative reentry initiatives. Contemporary Justice Review, 21(2), 159-184.

Lynn, V. (2019). Prison autobiographical narratives: Making sense of personal and social (racial) transformation. Crime Media Culture. https://doi.org/10.1177/1741659019880111

Manza, J., \& Uggen, C. (2006). Locked out: Felon disenfranchisement and American democracy. New York: Oxford University Press.

Maruna, S. (2001). Making good: How ex-convicts reform and rebuild their lives. Washington, DC: American Psychological Association.

Maruna, S., \& LeBel, T. P. (2009). Strengths-based approaches to reentry: Extra mileage toward reintegration and destigmatization. Japanese Journal of Sociological Criminology, 34, 59-81.

Mauer, M., \& Chesney-Lind, M. (2002). Invisible punishment: The collateral consequences of mass imprisonment. New York: The New Press.

McAnany, P., \& Tromanhauser, E. (1977). Organizing the convicted: Self-help for prisoners and exprisoners. Crime and Delinquency, 23(1), 68-74.

Miller, R. J., \& Alexander, A. (2016). The price of carceral citizenship: Punishment, surveillance, and social welfare policy in an age of carceral expansion. Michigan Journal of Race and Law, 21(2), 291-314.

Miller, R. J., \& Stuart, F. (2017). Carceral citizenship: Race, and rights and responsibility in the age of mass supervision. Theoretical Criminology, 21(4), 532-548.

Milovanovic, D. (1997). Postmodern criminology. New York: Taylor \& Francis.

Mobley, A. (2003). Convict criminology: The two-legged data dilemma. In J. Ross \& S. Richards (Eds.), Convict criminology (pp. 209-226). Belmont, CA: Wadsworth/Thomson Learning.

National Research Council. (2014). The growth of incarceration in the United States: Exploring causes and consequences. Washington, DC: The National Academies Press.

Newbold, G. (1998). The 1997 firearms review: An appraisal. Social Policy Journal, 11(December), $115-130$.

Page, J. (2011). The toughest beat: Politics, punishment, and the prison officers union in California. New York: Oxford University Press.

Pager, D. (2008). Marked: Race, crime, and finding work in an era of mass incarceration. Chicago, IL: The University of Chicago Press.

Polletta, F. (2006). It was like a fever: Storytelling in protest and politics. Chicago, IL: The University of Chicago Press.

Reiman, J., \& Leighton, P. (2016). The rich get richer and poor get prison (11th ed.). New York: Routledge.

Richards, S. C. (2013). The new school of convict criminology thrives and matures. Critical Criminology: An International Journal, 21(3), 375-387.

Richards, S. C., \& Jones, R. S. (1997). Perpetual incarceration machine: Structural impediments to postprison success. The Journal of Contemporary Criminal Justice, 13(1), 4-22.

Ross, J. I. (2009). Resisting the carceral state: Prisoner resistance from the bottom up. Social Justice, $36(3), 28-45$.

Ross, J. I., Darke, S., Aresti, A., Newbold, G., \& Earle, R. (2014). Developing convict criminology beyond North America. International Criminal Justice Review, 24(2), 121-133.

Ross, J. I., Jones, R. S., Lenza, M., \& Richards, S. C. (2016). Convict criminology and the struggle for inclusion. Critical Criminology: An International Journal, 24(4), 489-501.

Ross, J. I., \& Richards, S. C. (2003). Convict criminology. Belmont, CA: Wadsworth/Thomson Learning.

Sandel, M. J. (2009). Justice: What's the right thing to do? New York: Farrar, Staus and Giroux.

Seeds, C. (2017). Bifurcation nation: American penal policy in late mass incarceration. Punishment \& Society, 19(5), 590-610.

Shah, R. (2017). The meaning of rehabilitation and its impact on parole: There and back again in California. New York: Routledge.

Simon, J. (2007). Governing through crime: How the war on crime transformed American democracy and created a culture of fear. New York: Oxford University Press. 
Slessarev-Jamir, H. (2011). Prophetic activism: Progressive religious justice movements in contemporary America. New York: NYU Press.

Smiley, C. (2014). Existing but not living: Neo-civil death and the carceral state. Ph.D. dissertation. Graduate Center, City University of New York. Retrieved on November 19, 2020, from https:// academicworks.cuny.edu/.

Smiley, C. (2019). Release in the era of BLM: The nexus of black lives matter and prisoner reentry. The Prison Journal, 99(4), 396-419.

Strolovitch, D. Z. (2008). Affirmative advocacy: Race, class, and gender in interest group politics. Chicago, IL: The University of Chicago Press.

Sykes, G. (1958). The society of captives. Princeton, NJ: Princeton University Press.

Thomas, J. (1988). Prisoner litigation: The paradox of the jailhouse lawyer. Totowa, NJ: Rowman \& Littlefield.

Thompson, H. A. (2017). Blood in the water: The attica uprising of 1971 and its legacy. New York: Pantheon.

Tietjen, G. (2019). Convict Criminology: Learning from the Past, Taking on the Present, Expanding to Meet the Future. Critical Criminology: An International Journal 27(1), 101-114. https://doi.org/10.1007/ s10612-019-09436-w.

Truth and Reconciliation Commission. (1998). Truth and Reconciliation Commission of South Africa Report (Vol. 1). Retrieved on November 16, 2020, from https://www.justice.gov.za/trc/report/.

Wacquant, L. (2009). Punishing the poor: The neoliberal government of social insecurity. Durham, NC: Duke University Press.

Weaver, V., \& Lerman, A. E. (2010). The political consequences of the carceral state. American Politcal Science Review, 104(4), 817-833.

Werth, R. (2012). I do what I'm told, sort of: Reformed subjects, unruly citizens, and parole. Theoretical Criminology, 16(3), 329-346.

Western, B. (2006). Punishment and inequality in America. New York: Russell Sage Foundation.

Williams, J. (2019). Race as carceral terrain: Black Lives Matter meets reentry. The Prison Journal, 99(4), 387-395.

Wozniak, J. F., Braswell, M. C., \& Vogel, R. E. (2008). Transformative justice: Critical and peacemaking themes influenced by Richard Quinney. Lanham, MD: Lexington Books.

Zehr, H. (2015). Changing lenses: Restorative justice for our times. Harrisonburg, VA: Herald Press.

Publisher's Note Springer Nature remains neutral with regard to jurisdictional claims in published maps and institutional affiliations. 